\title{
Lung Non-Hodgkin Lymphoma
}

National Cancer Institute

\section{Source}

National Cancer Institute. Lung Non-Hodgkin Lymphoma. NCI Thesaurus. Code C5684.

A rare non-Hodgkin lymphoma that arises in and is confined to the lung at the time of diagnosis. Representative examples include bronchial mucosa-associated lymphoid tissue lymphoma and diffuse large B-cell lymphoma. 